\title{
Innovation management of regional economics (in terms of economic indicators of Saint Petersburg)
}

\author{
Alexander Samoylov ${ }^{1}$, Victor Abannikov ${ }^{2}$, Irina Zhulega ${ }^{1 *}$, and Artur Budagov ${ }^{1}$ \\ ${ }^{1}$ State University of Aerospace Instrumentation, Bolshaya Morskaya str. 67, Saint Petersburg, \\ 190000, Russia. \\ ${ }^{2}$ Russian State Hudrometeorological University (RSHU), Voronezhskaya str, 79, St. Petersburg, \\ 192007, Russia.
}

\begin{abstract}
This article is dedicated to the research of innovation processes at the regional level. There patterns of innovation processes and innovation activity applying modern management approach are considered. There dynamics analysis of such regional innovation activity indicators as number of organizations that perform the research; technology innovations cost; research and development inner cost; investment in equity; volume shipped innovation products is made based on statistic data. As an example of nature of the impact of these indicators to innovation environment of the region, the authors used the economic data of Saint Petersburg city. Additionally, there dynamics of analysing indicators is established, the reasons of their increase and decrease in the various time periods under the influence of political and external-economic factors is detected. In summary, the conclusion on current intensification of innovation processes in Saint Petersburg that reflects on both innovation activity data and territorial infrastructure, is made. The common tendency to increase the region innovation activity exists, despite the decrease of the number of organisations that perform researches and developments. These findings, achieved based on completed research, can be used to forecast the region innovation activity level, as well as for optimization of innovative activity indicators of the companies.
\end{abstract}

\section{Introduction}

It is impossible to imagine modern economy without science, which has become productive force, along with man power and production goods. The interaction of science and economics or the process that implement results of research and development activities into the economic system cannot be imagined without such discipline as innovation management.

The innovation management concept, referring to the knowledge-based system covering the field of innovation and modern management for development of high-tech innovations to be effectively implemented, is closely related to the concepts of innovation activity and

*Corresponding author: zhulega@mail.ru 
innovation process [1].

Innovation management at the present stage penetrates into all spheres of human activity. In the Russian Federation, as in most developed countries, innovations are actively manifested into the social, political and managerial (automation of business process management) spheres [2]. Having adopted the strategy for development of the Arctic zone and stated in Russia of 2019 as the year of ecology, it is noted diffusion of innovations in these areas of activity $[3,4]$. Beside addressing to the previously identified priority areas, innovative processes are aimed at implementing the strategic goals of the structural adjustment of industry and economy, both at regional scale and the Russian Federation scale $[5,6]$.

Understanding the laws of innovation process and innovation activity requires constant monitoring of the results of this process based on high-quality data, since only due to this we may understand the innovation state in the regions and in the country as a whole [7].

When monitoring the results of innovation, it is necessary to select indicators that will give the full understanding of structure and features of the innovation process for developing of policies and strategies. The selection of indicators and the monitoring methodology applies in strict accordance with the Oslo Guidelines as international recommendations for data acquisition and analysis in the innovation sphere [9].

To assess the current dynamics of innovation activity in a particular region (in the country), it is necessary to solve the problem of choosing homogeneous indicators as recommended in the Oslo Guidelines. This paper has task is to assess innovative activity in St. Petersburg over the past two decades.

\section{Assessment of indicators of innovative activity}

As the primary data source used in the article is the statistical reporting of organizations and companies, submitted to the regional branches of the Russian Federation Federal State Statistics Service. Subsequently, these data are systematized and published in the "Russian Statistical Yearbook" and in the Statistical Compilation "Russian Regions (Socio-Economic Indicators)". Both Collections contain the Section "Science and Innovation" [Statistical Yearbook. Regions of Russia. Socio-Economic Indicators. - M.: Rosstat, 2017/ http://www.gks.ru].

Existing indicators of innovation activity can be grouped into categories.

Indicators of the innovative activity results are set of indicators characterizing the implementation results of new or improved products and technology processes.

They include the following groups of indicators:

1. indicators of innovative products ratio (introduced over 3 years) in its total volume of new products, improved products and other innovative products;

2. indicators characterizing the impact of innovation on the business performances of companies:

- the amount of sale profit from the innovative products, and its share in the total amount of profit;

- the volume of sales of innovative products in foreign and domestic markets and their share in total sales;

- access to new markets;

- share in traditional markets.

3. indicators characterizing the cost reduction as the implemenatation result of innovations or the impact of innovation on the use of production resources (cost reduction, saving of energy and resources, increasing of capital productivity, etc.)

Indicators of the level of innovative activity of companies are relative indicators characterizing the degree of participation of companies in the implementation of innovative 
activities.

The level of innovation activity of companies is defined as the ratio of the number of innovation-active companies, i.e. engaged in any type of innovation, to the total number of surveyed companies. [10]

The following indicators of innovative activity in St. Petersburg are considered in this paper: the number of organizations performing research and development; technology innovation costs; research and development inner costs; investment in equity; volume of shipped innovation products.

The choice of indicators of innovation activity is determined by desire to understand influence of various factors (economic conditions, sanctions, etc.) to innovation activity. By the dynamics trend of the number of innovative organizations, we can understand that since 2000 there has been their significant reduction (Figure 1.)

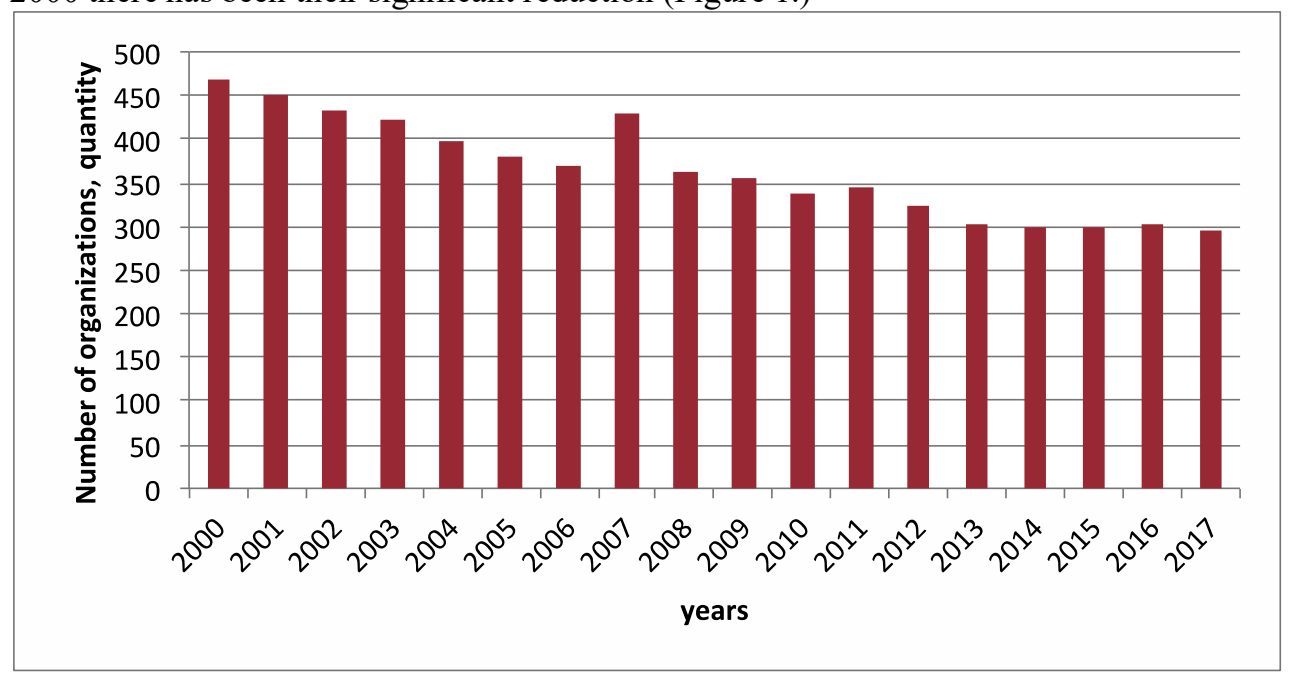

Fig. 1. The number of organizations engaged in research and development in St. Petersburg.

First of all, the reduction of innovative organizations is determined by the reduction of budgetary organizations in the research sector and can be traced throughout the study period. Slowdown features in this process begin to show in 2013. Since that time, despite the sanctions and the economy crisis in the Russian Federation, the number of innovative organizations in St. Petersburg has stabilized at 300 units. [11]

The following indicators of innovation activity (technology innovation cost and research and development inner cost) are completely different as compared with the number of innovative organizations (Figures 2 and 3 ). 


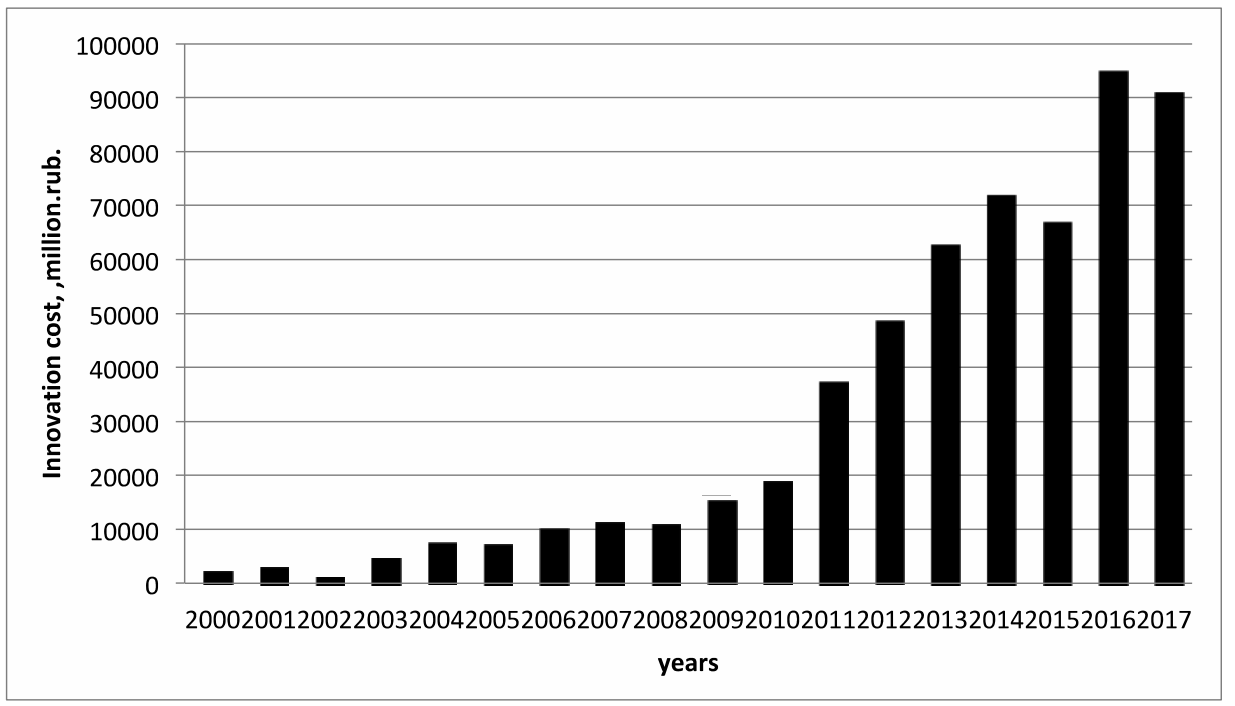

Fig. 2. Technology innovation cost (million RUB).

Figure 2 curve shows a consistent increase in technology innovation costs from 2000 to 2016, with exception of 2008 and 2015. The cose decrease in the first case can be explained by the beginning of global economic crisis caused by the mortgage-banking crisis in the United States, and in the second case are by sanctions. But in subsequent years happened a recovery and even excess of technology innovation costs. [12]

The sharp cost increase in 2016 was due to a political factor - the adoption of import substitution program by the Russian Federation Goverment. Against the background of this overestimated indicator, the 2017 `s result looks like a lower one, however, taking into account the political rather than economic nature of the 2016 s high indicator, we can say that this indicator is continuation of the general upward trend. [13]

Despite the reduction in the number of innovative organizations in St. Petersburg, the research and development (R\&D) inner costs in absolute indicators (million RUB) show steady growth having average annual increase of $17 \%$ over the study period (Figure 3 ).

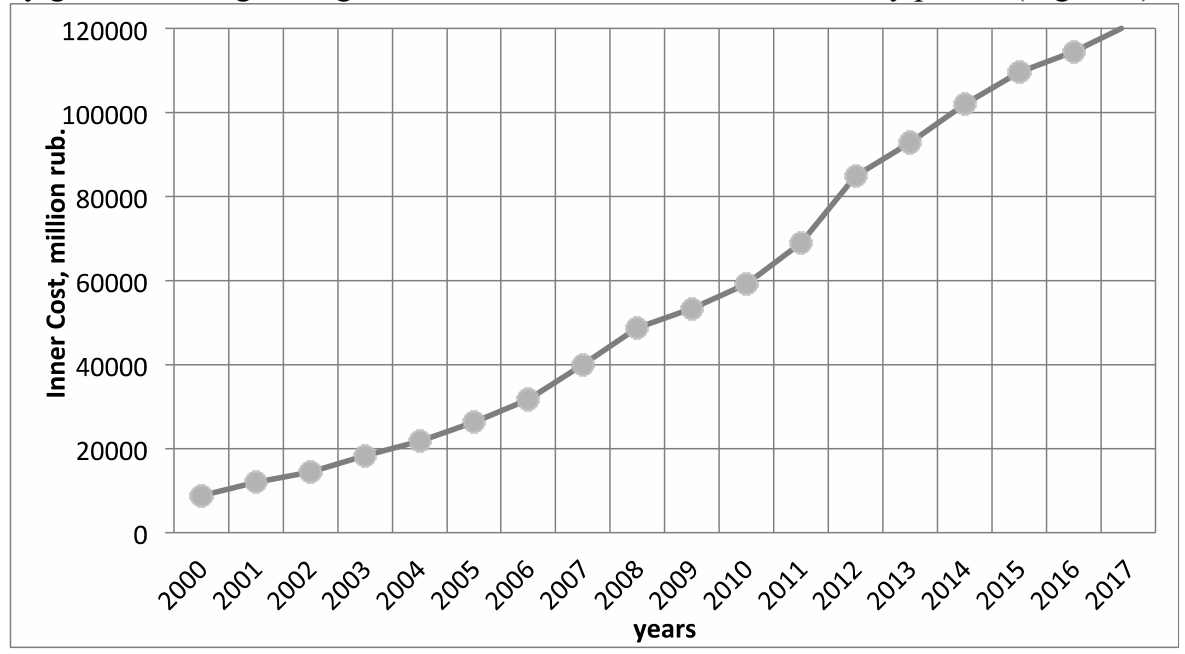

Fig. 3. Research and development inner cost (million RUB) 
If we calculate the annual growth rate of R\&D inner costs, we can see their gradual decrease starting in 2013 and stabilization in 2016 (Figure 4). Sharp drops were observed after the 2008`s crisis and with the beginning of the sanctions period in 2014.

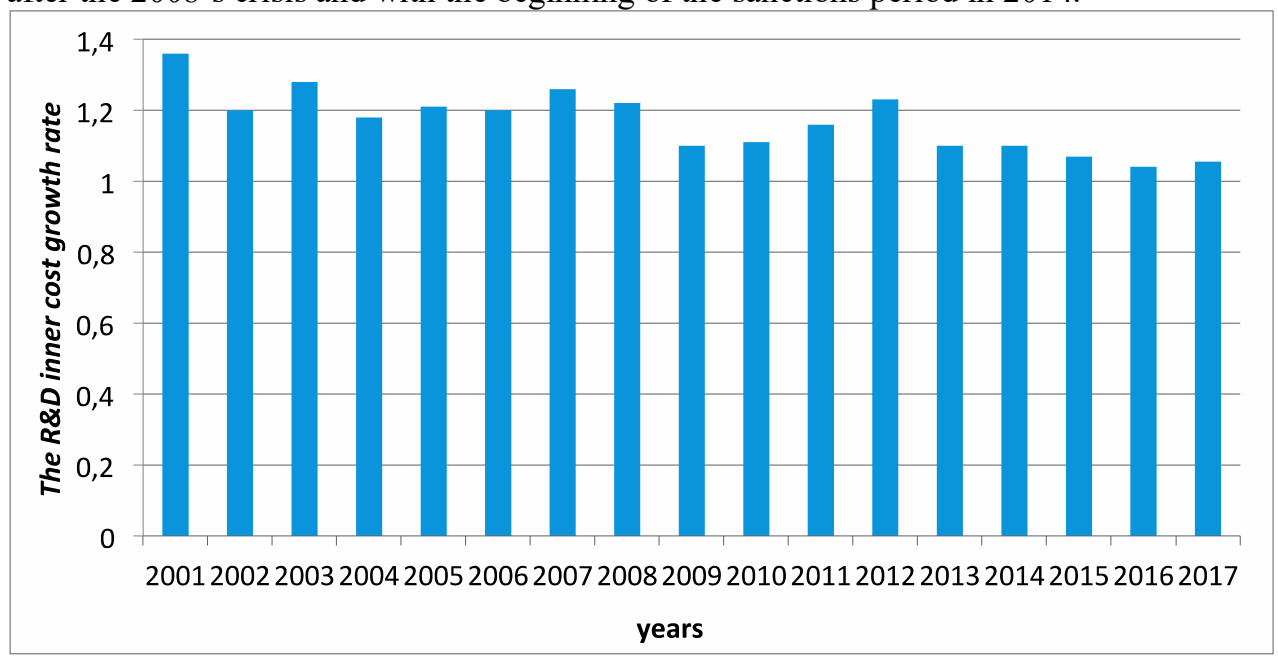

Fig 4. The R\&D inner cost growth rate

In view of the fact that the innovation sphere cannot exist without capital market, it is advisable to show the investment activity data, especially if this affects the problem of investment in organization's equity (Figure 5).

This is due to the fact that any innovative activity is directly related to the acquisition or installation of new equipment or technology, and this is impossible to carry out without additional capital investment. [14]

Figure 5 shows the investment flow dynamics into equity in St. Petersburg and this indicator is steadily increasing from year to year. Investment decrease occurs in 2009, 2013, 2015 and 2017. The first two reductions are due to banking crises, the third one is impostion of sanctions, and the fourth one is adjusted for extremely high growth in 2016, due to the political reasons mentioned above.

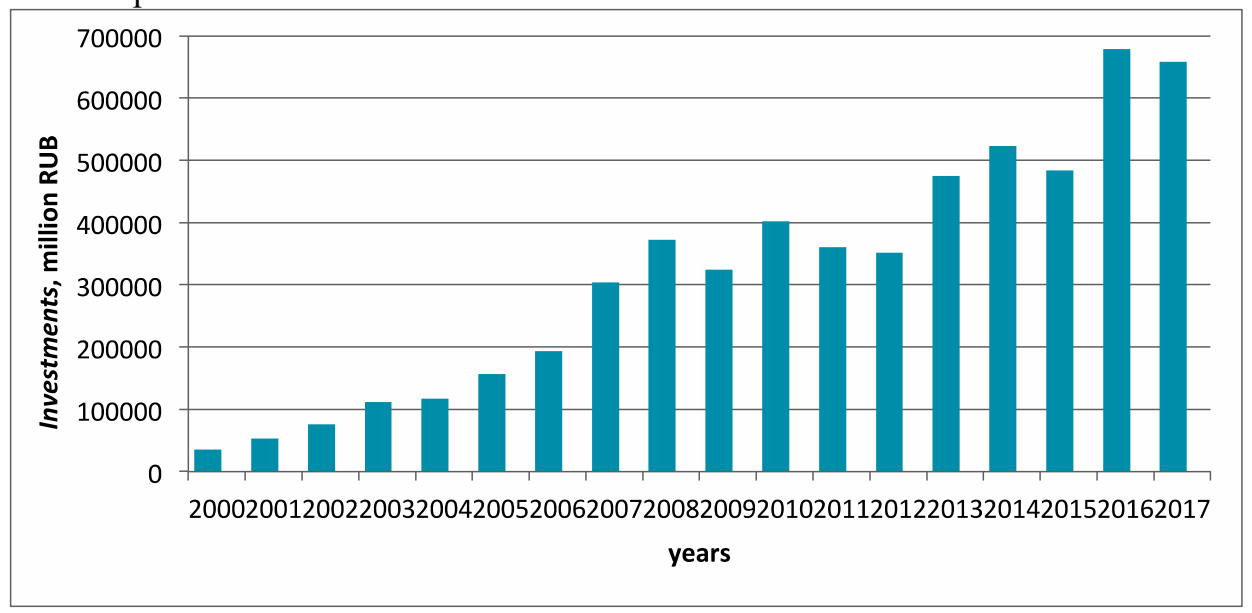

Fig. 5. Investments in equity (million RUB)

The growth in the volume of sold innovative products and rendered services is observed 
(both in absolute terms and in \%) from 2008 to 2012, after falling in 2007. Unfortunately, the increased costs of innovation and the volume of investments in equity did not contribute to the growth of sold innovative products in absolute indicator in 2013 and 2014, but on the contrary, this indicator decreased (Figure 6). But in the near future, from 2015 growth of shipped innovative products (services) begins again (Figure 6, Figure 7).

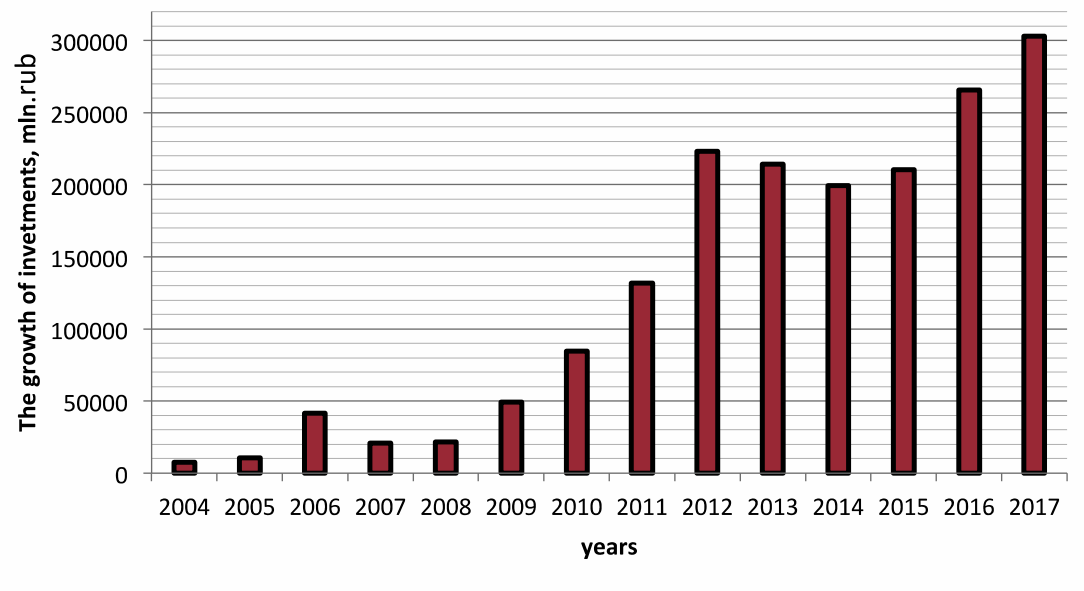

Fig. 6. Volumes of shipped innovative products, works and services.

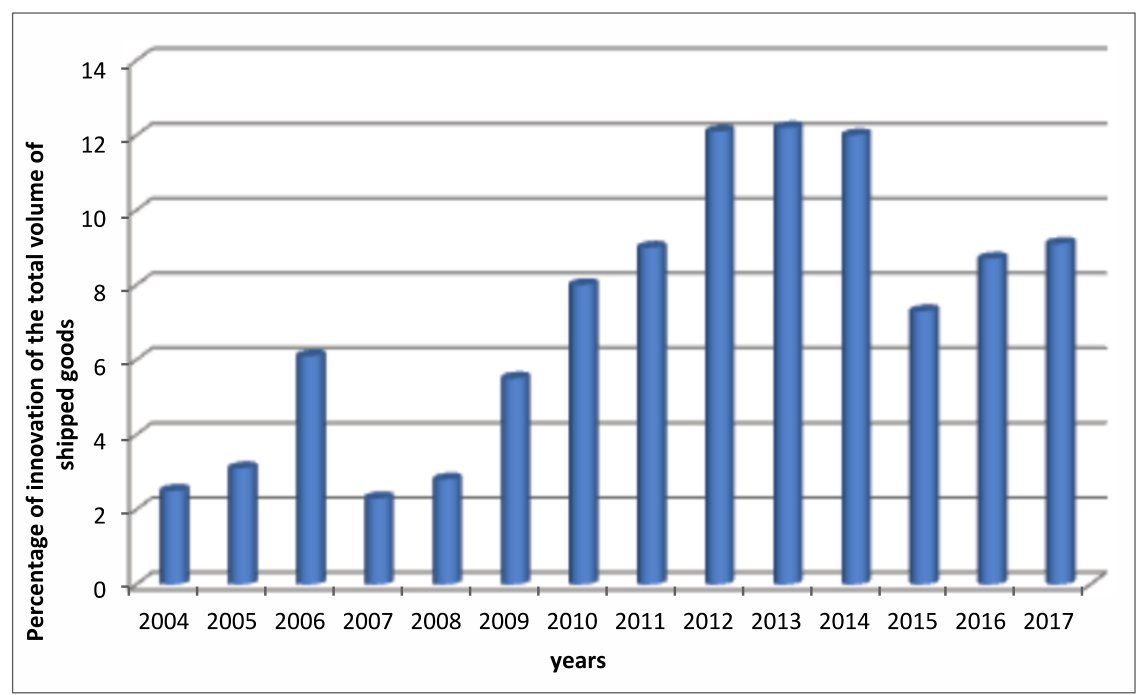

Fig. 7. Percentage of innovation of the total volume of shipped goods, performed works and rendered services.

Regarding the share of shipped innovative products from the total volume of products, it sharply falls by 2015 . Apparently, this was due to the need to implement the import substitution program, when companies tuned up the production of analogues of imported products and components. [15]

After launching the import substitution program, innovative companies, as can be seen from Figure 6 and Figure 7, restored plans for implementing their own innovations. 


\section{Conclusion}

Summing up the analysis of the dynamics of indicators of innovative activity in St. Petersburg, we can draw some conclusions. First of all, it should be noted that the number of innovative companies does not reflect the nature of innovation in the region. The current intensification of innovation processes in Saint Petersburg exists and reflects on both innovation activity indicators and territorial infrastructure. Against the background of decrease in the number of organizations, innovative activity in St. Petersburg is steadily increasing from year to year. This is evidenced by almost all analyzed indicators, with exception of individual years - 2008-2009, 2013 and 2015.

The reasons for decline in these years can be explained by the 2008's global crisis and the beginning of the policy of sanctions of Western countries in 2014 against the Russian Federation.

\section{References}

1. V. Ranta, J. Keränen, L. Aarikka-Stenroos. How B2B suppliers articulate customer value propositions in the circular economy: Four innovation-driven value creation logics. Industrial Marketing Management Available online 14 November 2019. (https://doi.org/10.1016/j.indmarman.2019.10.007)

2. T. Genzorova, T. Corejova, N. Stalmasekova. Transportation Research Procedia. 40, 1053-1058 (2019) (https://doi.org/10.1016/j.trpro.2019.07.147)

3. O. Popova, A. Starcev, M. Lunyakov and N. Fomenko. E3S Web of Conferences, 110, 01052 (2019) (https://doi.org/10.1051/e3sconf/201911001052)

4. I.G. Polyanskaya, V.V. Yurak Economy of the region. 13 (2). 355-368 (2017). https://doi 10.17059/2017-2-3

5. N. Gagulina, I. Zhulega and A. Samoylov. SHS Web Conf. 74 (2020). (https://doi.org/10.1051/shsconf/20207402005)

6. N. Goridko, R. Nizhegorodtsev. IFAC-PapersOnLine. 51(11), 868-875 (2018) (https://doi.org/10.1016/j.ifacol.2018.08.448)

7. H. Ben Brahim, S. Hadoussa. Journal of of Management Research, 10(3), p. 1-13 (2018) https://doi.org/10.5296/jmr.v10i3.13103)

8. D. Ahlstrom, J.L. Arregle, M.A. Hitt et al., Managing technological, sociopolitical, and institutional change in the new normal (2020) https://doi.org/10.1111/joms. 12569

9. Oslo Guidelines. Recommendations for data acquisition and analysis in innovation sphere. - ed. 3 rev. Joint publication of the OECD and Eurostat. - 107 p. (2010) https://doi.org/10.1787/19900414

10. N. Gagulina, A. Budagov and A. Novikov. E3S Web of Conferences, 110, 02108 (2019) https://doi.org/10.1051/e3sconf/201911002108

11. I.G. Polyanskaya, V.V. Yurak Economy of the region. 13(2). 355-368 (2017) https://doi 10.17059/2017-2-3

12. M. Tate, I. Bongiovanni, M. Kowalkiewicz, P. Townson. International Journal of Information Management, 39, 186-198 (2017) https://doi.org/10.1016/j.ijinfomgt.2017.11.008

13. W. Sutherland, M. H. Jarrahi. International Journal of Information Management. 43, 328-341 (2018) https://doi.org/10.1016/j.ijinfomgt.2018.07.004

14. A. Maffei, S. Grahn, C. Nuur. Procedia CIRP. 81, 765-770 (2019) https://doi.org/10.1016/j.procir.2019.03.191 
15. C. Watanabe, K. Naveed, Y. Tou, P. Neittaanmäki. Technological Forecasting and Social Change. 137, 226-240 (2018) https://doi.org/10.1016/j.techfore.2018.07.053 